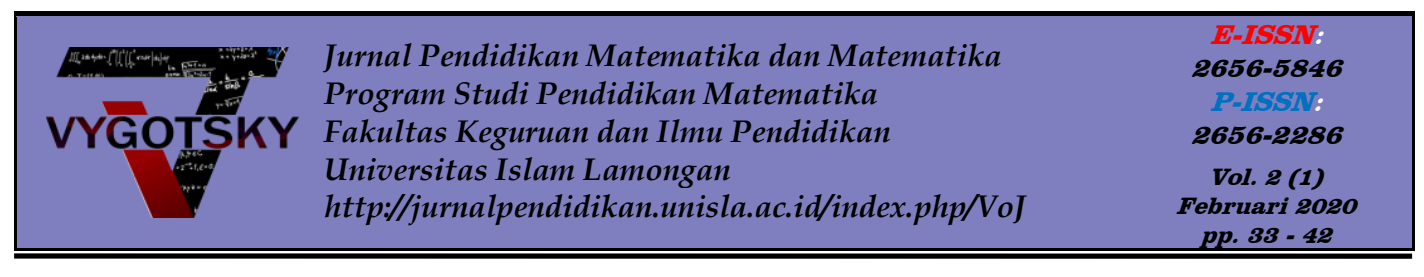

\title{
FAKTOR YANG MEMENGARUHI KEMAMPUAN PEMBUKTIAN MATEMATIS SISWA
}

\author{
(FACTORS AFFECTING STUDENTS' MATHEMATICAL PROVING \\ ABILITY)
}

Herizal Herizal ${ }^{1}$

1Universitas Malikussaleh, herizal_mathedu@unimal.ac.id

\begin{tabular}{l}
\hline \hline Info Artikel \\
\hline Received Feb 10, 2020 \\
Revised Feb 12, 2020 \\
Accepted Feb 26, 2020 \\
\hline
\end{tabular}

\section{Kata Kunci:}

Bukti Matematis

Kemampuan Pembuktian Matematis

\begin{abstract}
Mathematical proving is an important ability in learning mathematics. However, the students are difficult to expert in the ability. To overcome the problem, it needs to study factors affecting the ability. Thus, this study was conducted to study factors affecting mathematical proving ability. A questionnaire was given for 30 students of $10^{\text {th }}$ grade in one of senior high schools in Bandung, West Java, Indonesia. Each item was given a score and sorted from highest to low score, then the items were grouped into new factors based on the order of the score. The results showed that the experience factor was the strongest factor in influencing mathematical proof ability. The next factor was the ability, time, attitude and motivation, and teacher factor. The result become the theoritical basis in developing learning to improve mathematical proving ability.
\end{abstract}

\footnotetext{
Cara merujuk artikel

ini:

Herizal, H. (2020). Faktor

yang Memengaruhi

Kemampuan Pembuktian

Matematis Siswa. Vygotsky:

Jurnal Pendidikan

Matematika dan Matematika,

2 (1), pp. 33-42. Diunduh

dari https:/ /

jurnalpendidikan.

unisla.ac.id/index.php/VoJ

/article/view/187/pdf
}

Abstrak
Kemampuan pembuktian matematis merupakan
kemampuan penting dalam pembelajaran
matematika. Namun, kemampuan tersebut menjadi
kemampuan yang sulit dikuasai. Untuk mengatasi hal
itu, perlu dikaji faktor yang memengaruhi
kemampuan tersebut. Oleh karena itu, penelitian ini
dilakukan untuk melihat faktor yang memengaruhi
kemampuan pembuktian matematis. Kuesioner
diberikan kepada 30 siswa kelas X salah satu SMA
Swasta di Bandung. Masing-masing butir pernyataan
diberikan skor dan diurutkan dari tertinggi ke
rendah, selanjutnya beberapa butir pernyataan
tersebut dikelompokkan ke dalam faktor baru
berdasarkan urutan skor. Hasil menunjukkan faktor
pengalaman menjadi faktor terkuat bagi siswa dalam
memengaruhi kemampuan pembuktian matematis.
Faktor berikutnya adalah faktor kemampuan, waktu,
sikap dan motivasi, serta guru. Hasil tersebut
menjadi dasar dalam mengembangkan pembelajaran
untuk meningkatkan kemampuan pembuktian.

Copyright (C) 2020 Vygotsky: Jurnal Pendidikan Matematika dan Matematika. All right reserved 


\section{PENDAHULUAN}

Dalam belajar matematika, siswa dituntut untuk tidak hanya menyelesaikan soal rutin saja, tetapi juga dapat menyelesaikan soal nonrutin. Pemberian soal non-rutin kepada siswa dimaksudkan agar mereka terlatih untuk memiliki kemampuan berpikir matematis tingkat tinggi, seperti kemampuan pemecahan masalah dan kemampuan penalaran matematis. Dua kemampuan itu termasuk ke dalam beberapa kemampuan-kemampuan matematis yang harus dimiliki oleh siswa setelah belajar matematika (Permendikbud, 2016; NCTM, 2000; dan Kilpatrick, 2001).

Kemampuan pembuktian matematis merupakan kemampuan yang termasuk ke dalam kemampuan penalaran. Rumusan indikator kemampuan penalaran matematis dari beberapa sumber seperti dalam NCTM (2000) dan Hendriana, Rohaeti, \& Sumarmo (2017) menunjukkan bahwa salah satu indikator kemampuan penalaran matematis berkenaan dengan bukti matematis. Tergolongnya kemampuan pembuktian matematis sebagai bagian dari kemampuan penalaran matematis juga diperkuat dengan pendapat beberapa ahli. Brodie bersama dengan pakarpakar lainnya, yaitu Ball, Bass, Hanna, Jahnke, Davis, Hersh, Kilpatrick, dan Krumheuer sepakat menyatakan bahwa bukti adalah salah satu bentuk dari argumentasi dan justifikasi sehingga bisa dikatakan bahwa kemampuan pembuktian matematis merupakan bagian dari kemampuan penalaran matematis, meskipun banyak juga pendapat dimana pembuktian matematis disamakan dengan penalaran matematis (Brodie, 2010).

Pengajaran bukti matematis bagi siswa menurut Hersh (1993) adalah sebagai alat untuk membantu siswa memahami konsep matematika. Siswa akan mendapatkan pemahaman yang lebih baik mengenai suatu konsep matematika dengan adanya bukti matematis. Dickersen (dalam Doruk \& Kaplan, 2015) mengemukakan bahwa bukti matematis berguna untuk meningkatkan kemampuan berpikir kritis, penalaran dan berpikir matematika tingkat tinggi. Dua pendapat di atas menunjukkan bahwa kemampuan pembuktian matematis sangat penting bagi siswa.

Pentingnya kemampuan pembuktian matematis tidak sejalan dengan penguasaan siswa akan kemampuan tersebut. Penelitian Köğce \& Yildiz (2011) menunjukkan bahwa kemampuan pembuktian matematis siswa masih berada di bawah tingkatan yang diinginkan. Tidak hanya siswa, mahasiswa juga masih mengalami kesulitan dalam membuktikan suatu pernyataan matematis (Samparadja, 2014; Hamid, 2016)

Rendahnya kemampuan siswa dalam pembuktian matematis merupakan suatu masalah yang harus dipecahkan. Langkah pertama yang harus dilakukan adalah mengkaji faktor-faktor yang memengaruhi kemampuan pembuktian matematis tersebut. Oleh karena itu, penelitian ini dilakukan untuk mengetahui faktor-faktor yang memengaruhi kemampuan pembuktian matematis siswa. 


\section{METODE}

Dalam penelitian ini, peneliti ingin melihat faktor-faktor yang memengaruhi kemampuan pembuktian matematis siswa. Oleh karena itu, metode penelitian yang digunakan adalah metode kualitatif deskriptif. Partisipannya adalah 30 siswa kelas X salah satu SMA di Kota Bandung, Provinsi Jawa Barat, Indonesia. Keseluruhan siswa yang dipilih telah belajar proses pembuktian matematis pada topik trigonometri, lebih spesifiknya adalah membuktikan aturan sinus, aturan kosinus, dan rumus luas daerah segitiga. Setelah proses pembelajaran, siswa juga diberikan soal-soal yang memuat pembuktian matematis.

Setelah menyelesaikan soal, siswa diberikan kuesioner yang berisi pernyataan tentang faktor-faktor yang berkaitan dengan kemampuan siswa dalam menyelesaikan soal-soal bukti matematis. Kuesioner berupa skala likert dengan empat opsi jawaban, yaitu Sangat Setuju, Setuju, Tidak Setuju, dan Sangat Tidak Setuju. Sebelum diberikan ke siswa, kuesioner terlebih dahulu dinilai oleh dua ahli pendidikan matematika dan juga setelahnya diuji keterbacaan ke siswa.

Kuesioner yang telah diisi oleh siswa selanjutnya diberikan skor. Selanjutnya butir pernyataan diurutkan dari skor tertinggi ke skor terendah. Butir pernyataan dengan skor tertinggi dianggap sebagai faktor yang paling berpengaruh terhadap kemampuan pembuktian matematis siswa. Selain melalui kuesioner, data juga diperoleh melalui wawancara.

\section{HASIL DAN PEMBAHASAN}

Untuk mengetahui faktor-faktor yang mempengaruhi kemampuan pembuktian matematis siswa, kuesioner konfirmasi yang terdiri dari 15 butir pernyataan diberikan kepada siswa yang telah mengikuti tes kemampuan pembuktian matematis. Skor hasil respon siswa terhadap kuesioner yang diberikan untuk setiap butirnya yang telah diurutkan dari skor tertinggi ke terendah dapat dilihat pada Tabel 1 berikut.

Tabel 1. Skor Setiap Butir Pernyataan pada Kuesioner Konfirmasi

\begin{tabular}{|c|c|c|}
\hline Butir Ke- & PERNYATAAN & SKOR \\
\hline Butir 8 & $\begin{array}{l}\text { Saya kurang latihan soal-soal tentang pembuktian } \\
\text { matematis }\end{array}$ & 96 \\
\hline Butir 4 & $\begin{array}{l}\text { Saya tidak terbiasa dengan soal-soal tentang } \\
\text { pembuktian matematis }\end{array}$ & 91 \\
\hline Butir 7 & $\begin{array}{l}\text { Saya belum pernah mengerjakan jenis soal seperti } \\
\text { yang diujikan dalam tes }\end{array}$ & 90 \\
\hline Butir 6 & $\begin{array}{l}\text { Saya tidak paham maksud soal yang diberikan saat } \\
\text { tes }\end{array}$ & 86 \\
\hline Butir 5 & Saya tidak memahami materi yang diujikan saat tes & 85 \\
\hline Butir 9 & $\begin{array}{l}\text { Saya tidak dapat berkonsentrasi dengan baik karena } \\
\text { jam pelajaran matematika di siang hari }\end{array}$ & 84 \\
\hline Butir 14 & $\begin{array}{l}\text { Saya tidak dapat mengingat materi yang diujikan } \\
\text { dalam tes }\end{array}$ & 84 \\
\hline Butir 3 & Saya memiliki kemampuan matematika yang lemah & 83 \\
\hline
\end{tabular}




\begin{tabular}{|c|c|c|}
\hline Butir Ke- & PERNYATAAN & SKOR \\
\hline Butir 11 & Saya tidak tekun belajar pembuktian matematis & 76 \\
\hline Butir 10 & $\begin{array}{l}\text { Saya tidak tertarik dengan jenis soal yang diberikan } \\
\text { saat tes }\end{array}$ & 74 \\
\hline Butir 12 & $\begin{array}{l}\text { Saya tidak tertarik dengan topik matematika yang } \\
\text { berhubungan dengan pembuktian }\end{array}$ & 73 \\
\hline Butir 13 & $\begin{array}{l}\text { Saya mudah menyerah saat menyelesaikan soal-soal } \\
\text { pembuktian matematis }\end{array}$ & 72 \\
\hline Butir 15 & $\begin{array}{l}\text { Materi matematika yang diajarkan sebelumnya tidak } \\
\text { pernah dikaitkan dengan pembuktian }\end{array}$ & 65 \\
\hline Butir 2 & $\begin{array}{l}\text { Cara yang digunakan guru saat mengajar kurang } \\
\text { menarik }\end{array}$ & 62 \\
\hline Butir 1 & $\begin{array}{l}\text { Guru tidak mengajarkan tentang pembuktian } \\
\text { matematis }\end{array}$ & 47 \\
\hline
\end{tabular}

Tabel 2. Pengelompokan dan Penamaan Faktor Berdasarkan Skor

\begin{tabular}{|c|c|c|}
\hline \multirow{2}{*}{$\begin{array}{l}\text { Skor } \\
\geq 90\end{array}$} & Pernyataan & Nama Faktor \\
\hline & $\begin{array}{l}\text { Saya kurang latihan soal-soal tentang pembuktian } \\
\text { matematis } \\
\text { Saya tidak terbiasa dengan soal-soal tentang } \\
\text { pembuktian matematis } \\
\text { Saya belum pernah mengerjakan jenis soal seperti } \\
\text { yang diujikan dalam tes }\end{array}$ & $\begin{array}{l}\text { Faktor } \\
\text { Pengalaman }\end{array}$ \\
\hline $80-89$ & $\begin{array}{l}\text { Saya tidak paham maksud soal yang diberikan } \\
\text { saat tes } \\
\text { Saya tidak memahami materi yang diujikan saat } \\
\text { tes } \\
\text { Saya tidak dapat mengingat materi yang diujikan } \\
\text { dalam tes } \\
\text { Saya tidak dapat berkonsentrasi dengan baik } \\
\text { karena jam pelajaran matematika di siang hari }\end{array}$ & $\begin{array}{l}\text { Faktor } \\
\text { Kemampuan }\end{array}$ \\
\hline $70-79$ & $\begin{array}{l}\text { Saya tidak tekun belajar pembuktian matematis } \\
\text { Saya tidak tertarik dengan jenis soal yang } \\
\text { diberikan saat tes } \\
\text { Saya tidak tertarik dengan topik matematika yang } \\
\text { berhubungan dengan pembuktian } \\
\text { Saya mudah menyerah saat menyelesaikan soal- } \\
\text { soal pembuktian matematis }\end{array}$ & $\begin{array}{l}\text { Faktor Sikap } \\
\text { dan Motivasi }\end{array}$ \\
\hline$\leq 69$ & $\begin{array}{l}\text { Materi matematika yang diajarkan sebelumnya } \\
\text { tidak pernah dikaitkan dengan pembuktian } \\
\text { Cara yang digunakan guru saat mengajar kurang } \\
\text { menarik } \\
\text { Guru tidak mengajarkan tentang pembuktian } \\
\text { matematis }\end{array}$ & Faktor Guru \\
\hline
\end{tabular}

Dari Tabel 1, diperoleh total skor untuk masing-masing butir yang merupakan faktor-faktor yang mempengaruhi kemampuan pembuktian matematis siswa. Skor tertinggi menunjukkan faktor tersebut sangat berpengaruh terhadap kemampuan pembuktian matematis, sedangkan 
skor terendah sangat kecil pengaruhnya terhadap kemampuan pembuktian matematis siswa. Dari pengurutan total skor seperti pada Tabel 1, diperoleh empat kelompok skor, yaitu di atas 90, 80-89, 70-79, dan di bawah 69. Jika dilihat butir-butir pernyataan pada masing-masing dari 4 kelompok skor itu maka dapat dibentuk nama baru untuk kelompok tersebut. Pengelompokan dan nama baru untuk masing-masing kelompok skor, dapat dilihat pada Tabel 2.

Dari Tabel 2 di atas, diperoleh bahwa dalam penelitian ini faktor yang paling berpengaruh terhadap kemampuan pembuktian matematis siswa adalah faktor pengalaman, sedangkan faktor guru tidak terlalu berpengaruh. Urutan faktor yang sangat berpengaruh hingga kecil pengaruhnya adalah faktor pengalaman, faktor kemampuan, Faktor waktu, faktor sikap dan motivasi, serta faktor guru. Pembahasan kelima faktor tersebut adalah sebagai berikut.

a. Faktor Pengalaman

Dari hasil pengisian kuesioner diperoleh bahwa skor untuk butirbutir pernyataan seperti tidak terbiasa dengan soal-soal pembuktian, belum pernah mengerjakan jenis soal yang diujikan dalam tes, dan kurang latihan soal-soal tentang pembuktian matematis mendapatkan skor yang tinggi dibandingkan butir-butir pernyataan lain. Ini berarti, kemampuan pembuktian matematis siswa sangat dipengaruhi oleh faktor tersebut. Faktor-faktor tersebut jika dikelompokkan menjadi satu faktor baru bisa dinamakan faktor pengalaman. Pengalaman siswa dalam menyelesaikan soal-soal pembuktian matematis sangat penting. Siswa yang sudah terbiasa dengan pembuktian matematis tentu akan mempunyai nilai tambah saat diberikan tes kemampuan pembuktian matematis. Sebaliknya, siswa yang belum pernah diberikan soal-soal pembuktian tentu akan kesulitan dalam menyelesaikannya. Hasil wawancara dengan siswa yang masuk kelompok tinggi, sedang, dan rendah mengaku bahwa untuk jenis soal seperti soal tes kemampuan memahami bukti matematis yang diberikan, mereka baru pertama kali mendapatkannya. Selama ini mereka hanya mendapatkan soal-soal perhitungan biasa. Hal tersebut menyebabkan mereka, terutama siswa yang kemampuan sedang dan rendah, banyak yang tidak dapat menjawab soal pembuktian yang diberikan. Dengan demikian pengalaman siswa sebelumnya menjadi faktor penting. Mengenai pentingnya pengalaman dalam menyelesaikan soal-soal matematika juga sejalan dengan penelitian Suryawati, Budiman, \& Herizal (2014) yang memperoleh bahwa siswa dengan pengalaman yang lebih dalam matematika, misalnya pernah mengikuti olimpiade, pernah mengerjakan soal-soal PASIAD cenderung akan dapat menyelesaikan soal-soal nonrutin yang diberikan. Hal serupa juga disebutkan oleh Abdullah, Abidin, \& Ali (2015).

b. Faktor Kemampuan

Faktor berikutnya yang mempengaruhi kemampuan pembuktian 
matematis adalah faktor kemampuan yang dimiliki siswa. Kemampuan ini meliputi beberapa aspek seperti tidak paham maksud soal yang diberikan saat tes, tidak memahami materi yang diujikan, tidak dapat mengingat materi yang diujikan saat tes, dan memiliki kemampuan matematika yang lemah, misalnya kemampuan aritmetika. Kaeley (1993) menyebutkan kemampuan aritmetika memiliki korelasi yang tinggi dengan prestasi matematika. Hal serupa juga dinyatakan oleh Schiefele \& Csikszentmihalyi (1995) yang menjelaskan bahwa prestasi siswa dapat diprediksi dengan kuat oleh tingkatan kemampuan yang dimiliki siswa tersebut. Penjelasan tersebut menunjukkan bahwa kemampuan menjadi faktor yang sangat berpengaruh dalam belajar matematika termasuk belajar pembuktian matematis. Kemampuan yang dimiliki siswa dapat ditingkatkan melalui proses pembelajaran, misalnya untuk pembuktian matematis ini, guru perlu membiasakan siswanya dengan soal-soal pembuktian yang bervariasi.

c. Faktor Waktu

Waktu menjadi salah satu faktor yang harus diperhatikan dalam pembelajaran, terutama pelajaran matematika yang membutuhkan konsentrasi tinggi. Sebagian siswa menyatakan bahwa konsentrasi mereka saat belajar matematika di siang hari tidak sebaik saat pagi hari, apalagi dalam penelitian ditemukan bahwa jam pelajaran matematika di siang hari setelah jam pelajaran olahraga. Hal tersebut dibenarkan oleh Khodijah (2014) yang menyatakan waktu sebagai salah satu faktor yang mempengaruhi belajar dan hasil belajar. Sebagian siswa yang diwawancarai mengaku lebih mudah memahami pelajaran matematika di waktu pagi hari dibandingkan siang hari. Adapun pada kelas yang menjadi subjek penelitian, jam pelajaran matematika adalah di siang hari, sehingga faktor ini dominan dipilih oleh siswa sebagai faktor-faktor yang memengaruhi kemampuan pembuktian matematis.

d. Faktor Sikap dan Motivasi

Faktor ini terlihat dari beberapa pernyataan yang diberikan dalam kuesioner, yaitu tidak tekun belajar pembuktian, tidak tertarik dengan jenis soal yang diberikan saat tes, tidak tertarik dengan topik matematka yang berhubungan dengan pembuktian, dan mudah menyerah saat menyelesaikan soal-soal pembuktian. Sikap merupakan kecenderungan untuk mereaksi atau merespons terhadap suatu objek baik secara negatif atau positif. Secara umum, sikap siswa akan mempengaruhi belajar siswa (Syah, 2015). Sikap siswa terhadap soal-soal yang menyangkut kemampuan pembuktian matematis akan mempengaruhi kemampuan pembuktian yang ia miliki. Siswa yang memiliki sikap positif terhadap hal tersebut merupakan pertanda awal yang baik bagi kesuksesannya dalam pembuktian matematis. Sebaliknya, sikap negatif siswa terhadap pembuktian matematis akan menimbulkan kesulitan belajar bagi siswa. Oleh karena itu, penting 
untuk dapat mengubah sikap siswa terhadap pembuktian matematis. Salah satu cara untuk mengubah sikap siswa adalah dengan meyakinkan siswa akan manfaat pembuktian matematis. Dengan meyakini manfaat pembuktian matematis, siswa akan merasa membutuhkannya, dan dari perasaan itulah akan muncul sikap positif kepada pembuktian matematis.

Adapun motivasi juga penting dalam proses belajar karena motivasi dapat menentukan baik tidaknya dalam mencapai tujuan sehingga semakin besar motivasinya akan semakin besar kesuksesan belajarnya (Ahmadi \& Supriyono, 2013). Penelitian Muliaman, Suyanti, \& Eddiyanto (2018) menunjukkan bahwa terdapat hubungan antara motivasi dengan hasil belajar siswa. Dalam belajar matematika, Broussard \& Garrison (2004) menemukan bahwa motivasi berhubungan erat dengan nilai matematika yang tinggi. Seseorang yang memiliki motivasi kuat tentu tidak akan mudah menyerah dalam belajar dan menyelesaikan soal matematika termasuk soal-soal pembuktian matematis. Mereka akan berusaha dengan sungguhsungguh agar mampu mencapai hasil yang baik dalam proses belajar maupun saat tes pembuktian matematis.

e. Faktor Guru

Berdasarkan hasil kuesioner, faktor guru sangat kecil pengaruhnya terhadap kemampuan pembuktian matematis. Artinya mereka menganggap guru sudah melaksanakan proses pembelajaran yang mengakomodir kemampuan pembuktian matematis di dalamnya. Hasil tersebut dapat dilihat dari respon siswa pada beberapa butir pernyataan yang berhubungan dengan guru, yaitu guru tidak mengajarkan pembuktian matematis, cara mengajar guru yang kurang menarik, dan pembelajaran matematika tidak pernah dikaitkan dengan pembuktian. Perolehan skor untuk butir-butir tersebut sangat rendah, artinya siswa banyak yang memilih tidak setuju dan sangat tidak setuju akan pernyataan-pernyataan yang bernilai negatif tersebut. Hasil observasi di kelas juga menunjukkan bahwa guru sudah mengajarkan pembuktian matematis kepada siswa. Meskipun dalam penelitian ini, faktor guru kecil pengaruhnya sebab sudah melaksanakan tugasnya dengan baik. Namun secara umum dalam referensi tentang psikologi belajar, guru tetap dimasukkan sebagai salah satu faktor yang mempengaruhi hasil belajar siswa (Ahmadi \& Supriyono, 2013; Dimyati \& Mudjono, 2015; Khodijah, 2014; Syah, 2015). Pentingnya guru disebabkan gurulah yang memegang kendali selama proses pembelajaran. Bagaimana guru dalam menyampaikan suatu konsep sangat berpengaruh terhadap pemahaman siswa. Kreativitas guru dalam menyampaikan suatu materi sangat penting, misalnya penggunaan media saat menjelaskan suatu konsep tentu akan ada nilai tambahnya bagi siswa. Hasil penelitian menunjukkan bahwa pemahaman suatu konsep dapat ditingkatkan melalui penggunaan media pembelajaran 
(Sugiyarto, Ikhsan, \& Lukman, 2018). Selain media, peran guru juga ditentukan dalam pemilihan model/pendekatan/strategi pembelajaran yang tepat untuk meningkatkan hasil belajar siswa. Misalnya penggunaan strategi pembelajaran berbasis masalah akan berbeda hasilnya dengan pembelajaran inkuiri (Mellyzar, 2020). Di sinilah faktor guru ikut berperan terhadap penguasaan suatu kemampuan oleh siswa.

Dari kelima faktor yang telah dijelaskan di atas, faktor pengalaman menjadi faktor yang paling berpengaruh, artinya jika siswa tersebut sering mengerjakan soal-soal pembuktian suatu pernyataan matematis maka siswa tersebut kemungkinan besar akan sukses dalam suatu tes kemampuan pembuktian matematis. Namun, hal tersebut tidak berdiri sendiri, yaitu di sisi lain siswa juga harus memiliki kemampuan matematis yang memadai sebagai pendukung. Berkenaan dengan kemampuan, faktor guru berpengaruh di sini, yaitu guru memiliki peran dalam meningkatkan kemampuan siswa. Oleh karena itu, kelima faktor yang telah dibahas di atas saling terkait dan keseluruhannya berpengaruh terhadap kemampuan pembuktian matematis siswa, tetapi tingkat pengaruhnya berbeda-beda.

\section{KESIMPULAN DAN SARAN}

\section{Kesimpulan}

Setelah mempelajari matematika, salah satu kemampuan yang harus dimiliki oleh siswa adalah kemampuan pembuktian matematis. Kemampuan pembuktian matematis siswa SMA dipengaruhi oleh lima faktor utama, yaitu: 1) faktor pengalaman; 2) faktor kemampuan; 3) faktor waktu, 4) faktor sikap dan motivasi; dan 5) faktor guru. Dari kelima faktor tersebut, faktor yang paling berpengaruh adalah faktor pengalaman, artinya siswa yang sering diberikan soal-soal pembuktian matematis akan lebih besar peluang dapat mengerjakan soal-soal yang berkaitan dengan bukti matematis. Selain faktor tersebut, faktor kemampuan juga berpengaruh, namun pengaruhnya tidak sebesar faktor pengalaman. Jika diurutkan, kelima faktor tersebut yang pengaruhnya besar hingga kecil adalah faktor pengalaman, faktor kemampuan, faktor waktu, faktor sikap dan motivasi, serta faktor guru. Pada intinya, semua faktor-faktor tersebut berpengaruh pada kemampuan pembuktian matematis siswa, hanya saja tingkat pengaruhnya berbeda-beda.

\section{Saran}

Faktor yang paling berpengaruh terhadap kemampuan pembuktian matematis siswa adalah faktor pengalaman. Oleh karena itu, dalam proses pembelajaran matematika terutama pada materi yang sarat dengan pembuktian matematis, guru harus mengarahkan siswa ke pembuktian dan juga memberikan soal-soal yang tidak hanya bersifat 
rutin, tetapi juga soal nonrutin yang memuat pembuktian matematis.

\section{DAFTAR RUJUKAN}

Abdullah, A. H., Abidin, N. L. Z., \& Ali, M. (2015). Analysis of students errors in solving Higher Order Thinking Skills (HOTS) problems for the topic of fraction. Asian Social Science, 11(21), 133-142. https://doi.org/10.5539/ass.v11n21p133

Ahmadi, A., \& Supriyono, W. (2013). Psikologi Belajar. Jakarta: Rineka Cipta.

Brodie, K. (2010). Teaching Mathematical Reasoning in Secondary School Classrooms. New York: Springer. https://doi.org/10.1007/978-0-38709742-8

Broussard, S. C., \& Garrison, M. E. B. (2004). The relationship between classroom motivation and academic achievement in elementaryschool-aged children. Family and Consumer Sciences Research Journal, 33(2), 106-120.

Dimyati, \& Mudjono. (2015). Belajar dan Pembelajaran. Jakarta: Rineka Cipta.

Doruk, M., \& Kaplan, A. (2015). Prospective mathematics teachers' difficulties in doing proofs and causes of their struggle with proofs. 1st International Eurasian Educational Research Congress, 315-328.

Hamid, H. (2016). Kemampuan Pembuktian, Berpikir Kritis, dan Self-Efficacy Matematis Mahasiswa Melalui Model Rigorous Teaching and Learning (TL) dengan Memanfaatkan Argumen Informal. Sekolah Pascasarjana Universitas Pendidikan Indonesia. Bandung. Disertasi Doktor pada SPs UPI Bandung. (Tidak Diterbitkan).

Hendriana, H., Rohaeti, E. E., \& Sumarmo, U. (2017). Hard Skill dan Soft Skill Matematik Siswa. Bandung: Refika Aditama.

Hersh, R. (1993). Proving is convincing and expalining. Educational Studies in Mathematics, 24, 389-399.

Kaeley, G. S. (1993). Explaining mathematics achievement of mature internal and external students at the University of Papua New Guinea. Educational Studies in Mathematics, 25(3), 251-260.

Khodijah, N. (2014). Psikologi Pendidikan. Jakarta: RajaGrafindo Persada.

Kilpatrick. (2001). Adding it up: Helping Children Learn Mathematics. Washington, DC: National Reserach Council.

Köğce, D., \& Yildiz, C. (2011). A comparision of freshman and senior mathematics student teachers' views of proof concept. Procedia - Social and Behavioral Sciences, 15, 1266-1270. https:// doi.org/10.1016/j.sbspro.2011.03.274

Mellyzar. (2020). Penerapan strategi pembelajaran berbasis masalah dan inkuiri untuk meningkatkan hasil belajar siswa pada materi larutan penyangga. Genta Mulia, XI(1), 33-35.

Muliaman, A., Suyanti, R. D., \& Eddiyanto. (2018). Relationship between Motivation and College Students Learning Outcomes on Chemical Kinetic Material at University. Advances in Social Science, Education and 
Humanities Research, 200, 26-28.

NCTM. (2000). Principles and standards for school mathematics. Reston, VA.

Samparadja, H. (2014). Pengaruh Pendekatan Induktif-Deduktif Berbasis Definisi Termodifikasi dalam Pembelajaran Struktur Aljabar Terhadap Peningkatan Kemampuan Pembuktian da Disposisi Berpikir Kreatif Matematis Mahasiswa. Sekolah Pascasarjana Universitas Pendidikan Indonesia. Bandung. Disertasi Doktor pada SPs UPI Bandung. (Tidak Diterbitkan).

Schiefele, U., \& Csikszentmihalyi, M. (1995). Motivation and ability as factors in mathematics experience and achievement. Journal of Research in Mathematics Education, 26(2), 163-181.

Sugiyarto, K. H., Ikhsan, J., \& Lukman, I. R. (2018). The use of an android based-game in the team assisted individualization to improve students ' creativity and cognitive achievement in chemistry. Journal of Physics: Conference Series, 1022(12037), 1-7. https:// doi.org/10.1088/1742-6596/1022/1/012037

Suryawati, Budiman, \& Herizal. (2014). Analisis Kemampuan Problem Solving Siswa Kelas XI SMA Negeri Modal Bangsa Tahun Ajaran 2013/2014 dalam Menyelesaikan Masalah Aljabar. In M. Hidayat \& M. Nazar (Eds.), Prosiding Seminar Nasional dalam Rangka Konsorsium Perguruan Tinggi Indonesia-Pittsburgh (pp. 125-136). Banda Aceh: FKIP Unsyiah.

Syah, M. (2015). Psikologi Belajar. Jakarta: RajaGrafindo Persada. 